\title{
A Review on the Applications of Nanofluids in Cement Industry
}

\author{
Nadeem Ahmad Sheikh ${ }^{1,2,3}$ and Farhad Ali ${ }^{1,2,3}$, \\ 1Computational Analysis Research Group, Ton Duc Thang University, Vietnam \\ 2Faculty of Mathematics and Statistics, Ton Duc Thang University, Vietnam \\ 3Department of Mathematics, City University of Science and Information Technology, Pakistan
}

Submission: December 02, 2017; Published: February 21, 2018

*Corresponding author: Farhad Ali, Computational Analysis Research Group and Faculty of Mathematics and Statistics, Ton Duc Thang University, Ho Chi Minh City, Vietnam, Department of Mathematics, City University of Science and Information Technology, Peshawar, Khyber Pakhtunkhwa, Pakistan, Tel: +92-301-8882933; Email: farhad.ali@tdt.edu.vn

Abstract

In the last decade, theoretical and experimental research on nanofluids has been reported by many researchers because of their higher thermal conductivity as compared to base or common fluids. Although there are many controversial and inconsistent reports, the lack of understanding of the formation and mechanism of nanofluids further limits their applications. This article describes the application of nanofluids in the construction field.

Keywords: Nanofluids; CNTs; Building construction; Cement industry

\section{Introduction}

The fast paced technology development during the last decades of 20th century led to the appearance of several new materials suitable for the use in the building construction, such as phase change materials, nanomaterials and nanofluids which revealed many important and useful properties reported in the past decades [1]. The unique set of features of these materials offers unprecedented potential for various applications, including Building Integrated Solar Thermal Systems etc. The studies reported by the authors [2-6] established that the dispersion of the nanotubes into the mineral matrix increases its strength and density.

Cementations materials are often characterized as quasibrittle materials with low tensile strength and low strain capacity. Fibers can be incorporated into the cemented matrix to overcome these shortcomings [7]. The development of new nanosized fibers that can act as bridges across cracks and voids has opened a new field for nanosized reinforcement in concrete [8]. Carbon nanotubes (CNTs) are considered as one of the most advantageous nanomaterials for reinforcement purposes. The carbon nanotube dispersion structures the cementitious matrix in dense concrete and forms a dense, defect-free sleeve comprising cement and filler particles on the solid phase surface to provide a better cohesion with its surface [9].
Globally, the cement sector represents one of highest energy consumer among the other industries. The cost ofenergy consumption in the cement segment signifies $20 \%$ to $40 \%$ of the total production cost. As point to preceding studies, the energy consumption is between 4 and $5 \mathrm{GJ} /$ ton of cement. A considerable number of studies have been focused on the energy use and analysis in cement industry [10]. Among them, there are very imperative and deductive papers. Wang et al. [11] examined the waste heat recovery from the exhaust gases of pre-heater and clinker cooler using four kinds of cycles in order to cogeneration in a cement plant. Zamzamian et al. [12] investigated the coefficient of forced convective heat transfer for a double-pipe and plate heat exchangers using Al203-ethylene glycol and CuO-ethylene glycol nanofluids. Hadi [13], analyzed the effect of $\mathrm{Al} 2 \mathrm{O} 3$ nanoparticles in the cement industry for the closed recovery cycle.

\section{Conclusion}

1. Increasing the proportion of MWCNTs improves the elastic moduli of cement mainly by increasing the Poisson's ratio, so that the samples can withstand more stresses without being broken down.

2. Increase of working fluid inlet temperature and volume fraction of nanofluids in a closed recovery cycle causes 


\section{Civil Engineering Research Journal}

an increase in energy saving, cost saving and emissions reduction for each type of nanofluid.

3. The most important challenge in front of the scientist is the cost of nanoparticles, their synthesis, and instability and agglomeration problem. These problems need to be resolved in the coming future with improvement in nanotechnology.

\section{References}

1. Radulovic J, Nikolic D, Blagojevic M, Miletic I, Vaskovic M (2017) A review of new materials used for building integrated systems. In First International Conference on Building Integrated Renewable Energy Systems BIRES.

2. Makar JM, Beaudoin JJ (2004) Carbon nanotubes and their application in the construction industry. Special Publication-Royal Society of Chemistry 292: 331-342.

3. Xiang XJ, Torwald TL, Staedler T, Trettin RH (2006) Carbon nanotubes as a new reinforcement material for modern cement-based binders. In NICOM 2: 2nd International Symposium on Nanotechnology in Construction pp. 209-213.

4. Li GY, Wang PM, Zhao X (2005) Mechanical behavior and microstructure of cement composites incorporating surface-treated multi-walled carbon nanotubes. Carbon 43(6): 1239-1245.

5. Yakovlev G, Kerienė J, Plechanova T, Krutikov V (2007) Diskussionsforum: Nanobewehrung von Schaumbeton. Beton-und Stahlbetonbau 102(2): 120-124.

6. Al-Rub RKA, Ashour AI, Tyson BM (2012) On the aspect ratio effect of multi-walled carbon nanotube reinforcements on the mechanical properties of cementitious nanocomposites. Construction and Building Materials 35: 647-655.

7. Kuder KG, Shah SP (2010) Processing of high-performance fiberreinforced cement-based composites. Construction and Building Materials 24(2): 181-186

8. Park JM, Kim PG, Wang ZJ, Kwon DJ, De Vries KL (2011) Interfacial evaluation and self-sensing of single micro-carbon fiber/CNF-brittlecement composites using electro-micromechanical tests and acoustic emission. Advanced Composite Materials 20(2): 149-168.

9. Yakovlev G, Pervushin G, Maeva I, Keriene J, Pudov I (2013) Modification of construction materials with multi-walled carbon nanotubes. Procedia Engineering 57: 407-413.

10. Madlool NA, Hadi AAA (2015) Enhancement of waste heat recovery by using $\mathrm{Cu}$ nanoparticles in cement industries. Journal of Environmental Science 4(2): 12-15.

11. Wang J, Dai Y, Gao L (2009) Exergy analyses and parametric optimizations for different cogeneration power plants in cement industry. Applied Energy: 86(6): 941-948.

12. A Zamzamian, SN Oskouie, A Doosthoseini, A Joneidi, M Pazouki (2011) "Experimental investigation of forced convective heat transfer coefficient in nanofluids of Al203/EG and $\mathrm{CuO} / \mathrm{EG}$ in a double pipe and plate heat exchangers under turbulent flow". Exp Therm Fluid Sci 35: 495-502.

13. Hadi AAA (2015) Nanoparticles concentration and environmental effects on cogeneration system in cement industry. International Journal of Engineering Research and General Science 3(5): 786-798.
Your next submission with Juniper Publishers will reach you the below assets

- Quality Editorial service

- Swift Peer Review

- Reprints availability

- E-prints Service

- Manuscript Podcast for convenient understanding

- Global attainment for your research

- Manuscript accessibility in different formats

( Pdf, E-pub, Full Text, Audio)

- Unceasing customer service

Track the below URL for one-step submission https://juniperpublishers.com/online-submission.php 